\title{
Association of the rs7903146 single nucleotide polymorphism at the Transcription Factor 7-like 2 (TCF7L2) locus with type 2 diabetes in Brazilian subjects
}

\author{
Associação do polimorfismo de nucleotídeo único rs7903146 no \\ locus do TCF7L2 com diabetes tipo 2 em indivíduos brasileiros
}

Gustavo Barcelos Barra',2, Ludmila Alves Sanches Dutra', Sílvia Conde Watanabe ${ }^{3,4}$, Patrícia Godoy Garcia Costa' , Patrícia Sales Marques da $\mathrm{Cruz}^{3}$, Monalisa Ferreira Azevedo ${ }^{2,3}$, Angélica Amorim Amato ${ }^{2,3,4}$

\begin{abstract}
Objective: To investigate the association of the T allele of the single nucleotide polymorphism (SNP) rs7903146 of TCF7L2 with the occurrence of T2D in a sample of subjects followed up at the Brasilia University Hospital. Subjects and methods: The SNP rs7903146 of TCF7L2 was genotyped by allele-specific PCR in 113 patients with known T2D and in 139 non-diabetic controls in Brasilia, Brazil. Results: We found that the T allele of the SNP rs7903146 of TCF7L2 was significantly associated with T2D risk (odds ratio of 3.92 for genotype TT in the recessive genetic model, $\mathrm{p}=0.004$ and 1.5 for $\mathrm{T}$ allele, $\mathrm{p}=0.032$ ). Conclusion: These results reinforce previous findings on the consistent association of this genetic factor and the risk of T2D in populations of diverse ethnic backgrounds. Arq Bras Endocrinol Metab. 2012;56(8):479-84
\end{abstract}

Keywords

TCF7L2; single nucleotide polymorphism; type 2 diabetes; rs7903146

\section{RESUMO}

Objetivo: Investigar a associação do alelo T do polimorfismo de nucleotídeo único (SNP) rs7903146 do TCF7L2 com a ocorrência de DM2 em uma amostra de indivíduos acompanhados no Hospital Universitário de Brasília. Sujeitos e métodos: O SNP 7903146 do TCF7L2 foi genotipado por PCR alelo-específica em 113 pacientes portadores de DM2 e em 139 controles não diabéticos em Brasília, Brasil. Resultados: Foi observada associação significativa do alelo T do SNP rs7903146 do TCF7L2 com a ocorrência de DM2 (razão de chances de 3,92 para o genótipo TT utilizando o modelo genético recessivo, $p=0,003$; e de 1,5 para o aleloT, $p=0,032$ ). Conclusão: Esse resultado reforça os achados prévios de associação consistente desse fator genético com o risco de diabetes em populações de origens étnicas diversas. Arq Bras Endocrinol Metab. 2012;56(8):479-84

\section{Descritores}

TCF7L2; polimorfismo de nucleotídeo único; diabetes tipo 2; rs7903146
1 Unidade de Biologia Molecular, Instituto e Laboratório Sabin de Análises Clínicas, Brasília, DF, Brazil

2 Programa de Pós-Graduação em Ciências da Saúde, Universidade de Brasília (UnB), DF, Brazil ${ }^{3}$ Hospital Universitário de Brasília, UnB, DF, Brazil ${ }^{4}$ Laboratório de Farmacologia Molecular, Faculdade de Ciências da Saúde, Universidade de Brasília, Brazil
Correspondence to: Gustavo Barcelos Barra SEPS 710/910

Sul Edifício Via Brasil, loja 3 térreo, Asa Sul 70390-640 - Brasília, DF, Brazil gbarra@gmail.com

Received on July/31/2012 Accepted on Nov/8/2012

\section{INTRODUCTION}

$\mathrm{T}$ ype 2 diabetes (T2D) is a heterogeneous group of metabolic disorders characterized by the inability of pancreatic beta cells to increase insulin secretion in order to compensate for insulin resistance (1). It represents a significant worldwide burden due to the alarm- ing increase in its incidence over the last decades $(2,3)$, and because of its significant morbidity and mortality rates (4).

Environment and lifestyle changes are believed to play a primary role in the current epidemic of $\mathrm{T} 2 \mathrm{D}$, but the inherent susceptibility to the disease is widely 
attributed to complex genetic factors. There is compelling evidence that genetic susceptibility to the disease is polygenic, and genome-wide association studies have thus far identified almost 50 loci associated with T2D risk (5-8). Many of the genetic variants identified to date have been associated with small effect sizes, although single nucleotide polymorphisms (SNP) at the transcription factor 7-like 2 gene (TCF7L2) locus on chromosome $10 \mathrm{q}$ have been strongly and consistently associated with T2D risk in various populations and ethnic groups (6,9-11). An intronic SNP at this locus in particular, rs7903146, is considered the most important known genetic risk factor for T2D development (10).

TCF7L2 encodes the transcription factor TCF7L2, involved in the Wnt signaling pathway, which seems to be critical to pancreatic islet development and adipogenesis (12). TCF7L2 forms heterodimers with betacatenin to induce the expression of various genes, including the gene encoding the insulinotropic hormone glucagon-like peptide 1 (13), the insulin gene (14), and genes that encode proteins involved in processing and exocytosis of insulin granules (15). Although the mechanisms underlying the association of TCF7L2 polymorphisms and alterations in glucose homeostasis are not clear, these data suggest that this transcription factor primarily affects insulin secretion. TCF7L2 polymorphisms seem to influence beta cell function $(6,16$ 19) and insulin sensitivity (20-22).

Although disease association studies have shown that the T allele of the rs7903146 SNP at the TCF7L2 locus is strongly associated with T2D risk in diverse ethnic groups, it is noteworthy that the frequency of SNPs at this locus was shown to be different in the various populations included in these studies. The $\mathrm{T}$ allele of rs7903146 SNP at the TCF7L2 was seen in $18-42 \%$ of non-diabetic European and Arab populations (2325 ), but in less than $5 \%$ of healthy individuals in studies with Southeast Asian populations $(26,27)$. These data might suggest that the effect size of this SNP on T2D risk may vary among populations worldwide.

Marquezine and cols. reported that the $\mathrm{T}$ allele of rs7903146 SNP at the TCF7L2 locus is associated with a 1.57 increase in the risk of T2D in a sample of patients with documented multivessel coronary artery disease from the multivessel coronary disease patient studies (MASS II Study) in Southeastern Brazil, although this genetic variant did not increase the accuracy of a validated diabetes risk prediction score for the
Brazilian population (28). We have previously shown a $37 \%$ frequency of the T allele of rs7903146 SNP at the TCF7L2 locus in a group of 104 healthy young volunteers (mean age of $27.7 \pm 11$ years) randomly selected in Brasilia, the capital of Brazil (29). The Brazilian population represents a heterogeneous ethnic group, and Brasilia is a relatively young city; its population comprises individuals from almost all regions of the country. In this study, we describe the frequency of the alleles of the rs7903146 SNP at the TCF7L2 locus, and the association between the $\mathrm{T}$ allele of this polymorphism and the occurrence of T2D in a small sample of the population followed up at the Brasilia University Hospital.

\section{SUBJECTS AND METHODS}

\section{Subjects}

A total of 252 subjects were enrolled in this study, all from population seen at the Brasilia University Hospital, Brasilia, Brazil. The patients (113) were not related, aged over 40 years, and had been diagnosed with T2D after the age of 30 years, in accordance with 2006 American Diabetes Association (ADA) (30); individuals with features suggestive of other types of diabetes were excluded from the study. Control subjects (139) with normal glucose tolerance were also not related, aged over 40 years, and were seen for disorders not related to diabetes mellitus at the Brasilia University Hospital. Written informed consent was obtained from each participant after a full explanation of the study, which was approved by the Ethics Committee of the Health Sciences School from the University of Brasilia.

\section{Clinical and biochemical data}

The following clinical and biochemical data were obtained from the medical records of diabetic patients: family history of T2D, personal history of hypertension, dyslipidemia, hyperuricemia, nonalcoholic fatty liver disease, microvascular chronic complications (nephropathy, retinopathy, and neuropathy), smoking status (previous and current), presence of acantosis nigricans, body mass index (weight in $\mathrm{kg} /$ height in $\mathrm{m}^{2}$ ), waist circumference, fasting and postprandial blood glucose, serum lipid profile, serum urea, creatinine, uric acid, and liver enzymes. Complete information was not available for all patients. 


\section{rs7903146 genotyping}

A venous blood sample $(5 \mathrm{~mL})$ was obtained by peripheral venipuncture using disposable material and EDTA-containing tubes from each patient. All samples were collected at the Brasilia University Hospital. DNA was extracted by the Chelex-100 method (31), and rs7903146 genotype assays were conducted by allelespecific polymerase chain reaction. The primers and conditions for this reaction have been described elsewhere (29).

\section{Statistical analyses}

Categorical data were described in terms of absolute and relative frequencies, and were analyzed using Fisher's exact test. Numerical data were expressed as means \pm standard deviations. Hardy-Weinberg equilibrium and the association between disease status and the genetic variant were tested by Pearson's $\chi^{2}$ test, which was also used to find the best genetic model of inheritance that described effect of the rs7903146 SNP at the TCF7L2 locus. Odds Ratios, 95\% confidence intervals $(95 \% \mathrm{CI})$, and all statistical tests were carried out using GraphPad Prism version 5.00 for Windows, GraphPad Software, San Diego, California, USA (www.graphpad.com). A $p$ value $<0.05$ was considered statistically significant.

\section{RESULTS}

Mean age of patients was $58.6 \pm 9.8$ years, and $76.9 \%$ were female. In the control group, mean age was 56.5 \pm 9.9 years, and the majority was also female $(84.1 \%)$. Mean age $(\mathrm{p}=0.063)$ and gender distribution were $\operatorname{similar}\left(\chi^{2}=2.08, \mathrm{df}=1, \mathrm{p}=0.14\right)$ in both groups. Demographic, clinical, and biochemical parameters from T2D patients are described in table 1.

Allele and genotype frequencies of the rs7903146 SNP at TCF7L2 are summarized in table 2. Deviation from the Hardy-Weinberg equilibrium was not seen in either T2D $\left(\chi^{2}=3.14, \mathrm{df}=1, \mathrm{p}=0.08\right)$, or the control group $\left(\chi^{2}=1.03, \mathrm{df}=1, \mathrm{p}=0.31\right)$. Association analyses, which were performed using the chi-square test with 2 degrees of freedom, yielded a significant association between rs7903146 SNP of TCF7L2 and disease susceptibility $\left(\chi^{2}=8,7, \mathrm{df}=2, \mathrm{p}=0.012\right)$. To investigate in which model the effect of rs7903146 SNP at the TCF7L2 would fit, dominant, recessive, and co-dominant genetic models were considered (Table 2). Analy- sis performed in the recessive genetic model, with two copies of $\mathrm{T}$ being required for increased risk, yielded the strongest association between rs7903146 and T2D $\left(\chi^{2}=8.64, \mathrm{df}=1, \mathrm{p}=0.003\right.$; Table 2$)$. No significant associations were observed in the dominant $\left(\chi^{2}=1.22\right.$, $\mathrm{df}=1, \mathrm{p}=0.26)$ and co-dominant $\left(\chi^{2}=0.35, \mathrm{df}=1, \mathrm{p}\right.$ $=0.55)$ model of inheritance. Chi-square statistics also indicated a significant association between the TT genotype and T2D compared with the CC reference genotype $\left(\chi^{2}=8.3 ; \mathrm{df}=1 ; \mathrm{p}=0.004\right)$, and yielded an odds ratio of 4.04 (95\% CI; 1.48-11.0). The same analysis was carried out for heterozygotes, and it showed that the CT genotype was not significantly associated with $\mathrm{T} 2 \mathrm{D}\left(\chi^{2}=0.06, \mathrm{df}=1, \mathrm{p}=0.81\right)$, yielding an odds ratio of 1.07 (95\% CI; 0.63-1.80). Moreover, allelic odds ratio of rs7903146 T carriers was 1.51 (95\% CI; 1.03$2.21 ; \mathrm{P}=0.032$; Table 2 ).

Table 1. Clinical and biochemical characteristics of $T 2 D$ patients

\begin{tabular}{lcc}
\hline Characteristics of T2D patients & Mean \pm SD & $\mathbf{n}$ \\
\hline Age (years) & $58.6 \pm 9.8$ & 113 \\
Gender (female) & 76.9 & 113 \\
Current smoking (\%) & 7.9 & 89 \\
Previous smoking (\%) & 40.0 & 80 \\
Family history of diabetes (\%) & 79.3 & 87 \\
Acanthosis nigricans (\%) & 42.5 & 73 \\
Hypertension (\%) & 78.8 & 85 \\
Dyslipidemia (\%) & 77.2 & 79 \\
Hyperuricemia (\%) & 30.2 & 63 \\
Hepatic steatosis (\%) & 3.7 & 54 \\
Diabetic nephropathy (\%) & 35.3 & 68 \\
Diabetic retinopathy (\%) & 21.2 & 66 \\
Diabetic neuropathy (\%) & 26.6 & 79 \\
Body mass index (kg/m²) & $29.1 \pm 4.9$ & 78 \\
Waist circumference (cm) & $100.7 \pm 11.3$ & 47 \\
Fasting glucose (mg/dL) & $147.6 \pm 59.5$ & 66 \\
Postprandial glucose (mg/dL) & $209.2 \pm 108.7$ & 36 \\
Total cholesterol (mg/dL) & $203.4 \pm 56.9$ & 62 \\
HDL cholesterol (mg/dL) & $42.3 \pm 13.9$ & 62 \\
LDL cholesterol (mg/dL) & $118.2 \pm 43,1$ & 62 \\
Triglycerides (mg/dL) & $217 \pm 156.6$ & 62 \\
Urea (mg/dL) & $36.8 \pm 13.2$ & 61 \\
Creatinine (mg/dL) & $0.85 \pm 0.26$ & 61 \\
Uric acid (mg/dL) & $5.4 \pm 1.3$ & 43 \\
Alanine aminotransferase (U/L) & $22.6 \pm 8.7$ & 56 \\
Aspartate aminotransferase (U/L) & $23.39 \pm 10.2$ & 56 \\
\hline & & \\
\hline
\end{tabular}

$\mathrm{n}$ : total number of patients with data retrieved from hospital records; SD: standard deviation. 
Table 2. Genotypes, alleles, and statistical data of rs7903146 SNP at the TCF7L2 in diabetic and control subjects

\begin{tabular}{|c|c|c|c|c|}
\hline \multicolumn{5}{|c|}{ Genotype distribution } \\
\hline & CC & CT & TT & Total \\
\hline $\mathrm{T} 2 \mathrm{D}$ & 49 (43.4\%) & $47(41.6 \%)$ & $17(15 \%)$ & 113 \\
\hline Controls & $70(50.4 \%)$ & $63(45.6 \%)$ & $6(4.3 \%)$ & 139 \\
\hline Total & 119 & 110 & 23 & 252 \\
\hline \multicolumn{5}{|c|}{ Allelic distribution } \\
\hline & \multicolumn{2}{|c|}{ C } & $\mathbf{T}$ & Total \\
\hline $\mathrm{T} 2 \mathrm{D}$ & \multicolumn{2}{|c|}{$145(64.2 \%)$} & $81(35.8 \%)$ & 226 \\
\hline Controls & \multicolumn{2}{|c|}{$203(73 \%)$} & $75(27 \%)$ & 278 \\
\hline Total & \multicolumn{2}{|c|}{348} & 156 & 504 \\
\hline \multicolumn{5}{|c|}{ Genetic models and statistical data } \\
\hline Genetic Model & Odds ratio $(95 \% \mathrm{CI})$ & Chi-square & Degrees of freedom & $\mathbf{P}$ \\
\hline Association (CC vs. CT vs. TT) & & 8.70 & 2 & 0.012 \\
\hline Dominant (CT + TT vs. CC) & $1.32(0.80-2.18)$ & 1.22 & 1 & 0.260 \\
\hline Recessive (TT vs. CT + CC) & $3.92(1.49-10.3)$ & 8.64 & 1 & 0.003 \\
\hline Co-dominant (CT vs. CC + TT) & $1.16(0.70-1.92)$ & 0.35 & 1 & 0.55 \\
\hline Homozigote (CC vs. TT) & $4.04(1.48-11.0)$ & 8.30 & 1 & 0.004 \\
\hline Heterozigote (CC vs. CT) & $1.06(0.63-1.80)$ & 0.06 & 1 & 0.81 \\
\hline Allele (C vs. T) & $1.51(1.03-2.21)$ & 4.58 & 1 & 0.032 \\
\hline
\end{tabular}

\section{DISCUSSION}

The identification of genetic variants influencing T2D is a major focus of research to improve the understanding of the mechanisms underlying the pathogenesis of this disorder. Recent advances, such as the development of genome-wide association studies have enabled the identification of a number of genes associated with $\mathrm{T} 2 \mathrm{D}$ risk. In this scenario, common genetic variants in TCF7L2 gene were recently associated with T2D risk by Grant and cols. (9), and these findings were consistently reproduced in various populations $(6,10,11)$. Since then, TCF7L2 has been considered one of the most important known genetic risk factors for the development of the disease.

In this study, the association of the rs7903146 polymorphism at the TCF7L2 and diabetes risk was found in a small sample from the population of Brasilia, in the Central Western region of Brazil. The odds ratio for the association with genotype TT (recessive model) were 3.92 (CI 95\%; 1.49-10.3); and for T allele 1.51 (CI 95\%; 1.03-2.21), similar to that reported in the previous study involving the Brazilian population (28), as well as in other populations $(10,25,32)$. The T allele was significantly more frequent in T2D patients than in controls $(35.8 \%$ versus $27 \% ; \mathrm{p}=0.032)$. The frequency of the risk allele in the control group was similar to that described in non-diabetic European (Cauchi, 2006 and Gonzalez, 2008) and Arab (Ezzidi, 2009) populations, and higher than that reported in Southeast Asian populations, in which this variant occurs in less than $5 \%$ of the general population (Chang, 2007; Wen, 2010).

The frequency of the $\mathrm{T}$ allele of rs7903146 SNP at the TCF7L2 in both T2D and control subjects was lower than our previously reported frequency $(37 \%)$. The difference in the mean age of subjects enrolled in each study $(27.7 \pm 11$ versus $58.6 \pm 9.8$ and $56.5 \pm 9.9$ years in T2D and controls, respectively), and it is be possible that the subjects enrolled in the first study may be representative of a group at higher risk of developing T2D with advancing age, since the frequency of the $\mathrm{T}$ allele in this group was more similar than that found in T2D patients in this study.

Despite the strong association between rs7903146 polymorphism at the TCF7L2 and T2D risk in clinical studies, it is not readily apparent how this intronic TCF7L2 variant increases susceptibility to the disease. There is evidence that TCF7L2 has an important role in maintaining beta cell mass and function. This transcription factor itself seems to be critical for beta cell proliferation, protection against apoptosis, and insulin secretion $(14,33)$. In addition, it has been shown to be involved in the expression of glucagon-like peptide 1 , 
and gastric inhibitory peptide receptors in beta cells, which mediate the effects of the correspondent incretin hormones to promote beta cell proliferation, neogenesis, and survival in rodent models (34). More recently, TCF7L2 expression in the endocrine pancreas was correlated not only with beta cell proliferation, but also with beta cell regeneration in different murine models of diabetes (35). In the same study, it was shown that in human exocrine pancreatic tissue, TCF7L2 overexpression induced beta cell phenotype and insulin production in ductal epithelial cells (35).

Our results confirm the previous findings from Marquezine and cols. (28), who studied a population from a different region of Brazil. Replication of the association of this genetic variant with T2D risk in a small Brazilian sample reinforces the strength of this association in our population and worldwide. However, it is important to point out that in spite of all the efforts to understand how the T allele of SNP rs7903146 at the TCF7L2 is precisely related to T2D risk, clinical studies have failed to show that determination of TCF7L2 genotype adds to clinical criteria in determining the individual risk of the disease. Hence, although it is believed that knowledge of genetic factors associated with T2D risk has the potential to bring new perspectives to the development of more effective preventative and therapeutic strategies for the disease, there is a lot to be understood before this information can be translated into benefits in clinical practice.

Disclosure: no potential conflict of interest relevant to this article was reported.

\section{REFERENCES}

1. Stumvoll M, Goldstein BJ, van Haeften TW. Type 2 diabetes: principles of pathogenesis and therapy. Lancet. 2005;365(9467):1333-46.

2. Zimmet P, Alberti KG, Shaw J. Global and societal implications of the diabetes epidemic. Nature. 2001;414(6865):782-7.

3. Wild S, Roglic G, Green A, Sicree R, King H. Global prevalence of diabetes: estimates for the year 2000 and projections for 2030. Diabetes Care. 2004;27(5):1047-53.

4. van Dieren S, Beulens JW, van der Schouw YT, Grobbee DE, Neal B. The global burden of diabetes and its complications: an emerging pandemic. Eur J Cardiovasc Prev Rehabil. 2010;17 Suppl 1:S3-8.

5. Sladek R, Rocheleau G, Rung J, Dina C, Shen L, Serre D, et al. A genome-wide association study identifies novel risk loci for type 2 diabetes. Nature. 2007;445(7130):881-5.

6. Saxena R, Voight BF, Lyssenko V, Burtt NP, de Bakker PI, Chen H, et al. Genome-wide association analysis identifies loci for type 2 diabetes and triglyceride levels. Science. 2007;316(5829):1331-6.

7. Zeggini E, Scott LJ, Saxena R, Voight BF, Marchini JL, Hu T, et al. Meta-analysis of genome-wide association data and large-scale replication identifies additional susceptibility loci for type 2 diabetes. Nat Genet. 2008;40(5):638-45.

8. Voight BF, Scott LJ, Steinthorsdottir V, Morris AP, Dina C, Welch RP, et al. Twelve type 2 diabetes susceptibility loci identified through large-scale association analysis. Nat Genet. 2010;42(7):579-89.

9. Grant SF, Thorleifsson G, Reynisdottir I, Benediktsson R, Manolescu A, Sainz J, et al. Variant of transcription factor 7-like 2 (TCF7L2) gene confers risk of type 2 diabetes. Nat Genet. 2006;38(3):320-3.

10. Cauchi S, El AchhabY, Choquet H, Dina C, Krempler F, Weitgasser $R$, et al.TCF7L2 is reproducibly associated with type 2 diabetes in various ethnic groups: a global meta-analysis. J Mol Med (Berl). 2007;85(7):777-82.

11. Scott LJ, Bonnycastle LL, Willer CJ, Sprau AG, Jackson AU, Narisu N, et al. Association of transcription factor 7-like 2 (TCF7L2) variants with type 2 diabetes in a Finnish sample. Diabetes. 2006;55(9):2649-53.

12. Prestwich TC, Macdougald OA. Wnt/beta-catenin signaling in adipogenesis and metabolism. Curr Opin Cell Biol. 2007;19(6):612-7.

13. Yi F, Brubaker PL, Jin T. TCF-4 mediates cell type-specific regulation of proglucagon gene expression by beta-catenin and glycogen synthase kinase-3beta. J Biol Chem. 2005;280(2):1457-64.

14. Loder MK, da Silva Xavier G, McDonald A, Rutter GA. TCF7L2 controls insulin gene expression and insulin secretion in mature pancreatic beta-cells. Biochem SocTrans. 2008;36(Pt 3):357-9.

15. da Silva Xavier G, Loder MK, McDonald A, Tarasov Al, Carzaniga $R$, Kronenberger $K$, et al. TCF7L2 regulates late events in insulin secretion from pancreatic islet beta-cells. Diabetes. 2009;58(4):894-905.

16. Florez JC, Jablonski KA, Bayley N, Pollin TI, de Bakker PI, Shuldiner AR, et al. TCF7L2 polymorphisms and progression to diabetes in the Diabetes Prevention Program. N Engl J Med. 2006;355(3):241-50.

17. Lyssenko V, Lupi R, Marchetti P, Del Guerra S, Orho-Melander $M$, Almgren $P$, et al. Mechanisms by which common variants in the TCF7L2 gene increase risk of type 2 diabetes. J Clin Invest. 2007;117(8):2155-63.

18. Munoz J, Lok KH, Gower BA, Fernandez JR, Hunter GR, LaraCastro $\mathrm{C}$, et al. Polymorphism in the transcription factor 7-like 2 (TCF7L2) gene is associated with reduced insulin secretion in nondiabetic women. Diabetes. 2006;55(12):3630-4.

19. Wang J, Kuusisto J, Vanttinen M, Kuulasmaa T, Lindstrom J, Tuomilehto J, et al. Variants of transcription factor 7-like 2 (TCF7L2) gene predict conversion to type 2 diabetes in the Finnish Diabetes Prevention Study and are associated with impaired glucose regulation and impaired insulin secretion. Diabetologia. 2007;50(6):1192-200.

20. Elbein SC, Chu WS, Das SK, Yao-Borengasser A, Hasstedt SJ, Wang $H$, et al. Transcription factor 7-like 2 polymorphisms and type 2 diabetes, glucose homeostasis traits and gene expression in US participants of European and African descent. Diabetologia. 2007;50(8):1621-30.

21. Damcott CM, Pollin TI, Reinhart LJ, Ott SH, Shen H, Silver KD, et al. Polymorphisms in the transcription factor 7-like 2 (TCF7L2) gene are associated with type 2 diabetes in the Amish: replication and evidence for a role in both insulin secretion and insulin resistance. Diabetes. 2006;55(9):2654-9.

22. Musso G, Gambino R, Pacini G, Pagano G, Durazzo M, Cassader M. Transcription factor 7-like 2 polymorphism modulates glucose and lipid homeostasis, adipokine profile, and hepatocyte apoptosis in NASH. Hepatology. 2009;49(2):426-35.

23. Ezzidi I, Mtiraoui N, Cauchi S, Vaillant E, Dechaume A, Chaieb M, et al. Contribution of type 2 diabetes associated loci in the Arabic population from Tunisia: a case-control study. BMC Med Genet. 2009;10:33. 
24. Gonzalez-Sanchez JL, Martinez-Larrad MT, Zabena C, PerezBarba M, Serrano-Rios M. Association of variants of the TCF7L2 gene with increases in the risk of type 2 diabetes and the proinsulin:insulin ratio in the Spanish population. Diabetologia. 2008;51(11):1993-7.

25. Cauchi S, Meyre D, Dina C, Choquet H, Samson C, Gallina S, et al. Transcription factor TCF7L2 genetic study in the French population: expression in human beta-cells and adipose tissue and strong association with type 2 diabetes. Diabetes. 2006;55(10):2903-8.

26. Wen J, Ronn T, Olsson A, Yang Z, Lu B, Du Y, et al. Investigation of type 2 diabetes risk alleles support CDKN2A/B, CDKAL1, and TCF7L2 as susceptibility genes in a Han Chinese cohort. PloS one. 2010;5(2):e9153.

27. Chang YC, Chang TJ, Jiang YD, Kuo SS, Lee KC, Chiu KC, et al. Association study of the genetic polymorphisms of the transcription factor 7-like 2 (TCF7L2) gene and type 2 diabetes in the Chinese population. Diabetes. 2007;56(10):2631-7.

28. Marquezine GF, Pereira AC, Sousa AG, Mill JG, Hueb WA, Krieger JE. TCF7L2 variant genotypes and type 2 diabetes risk in Brazil: significant association, but not a significant tool for risk stratification in the general population. BMC Med Genet. 2008;9:106.
29. Dutra LA, Costa PG, Velasco LF, Amato AA, Barra GB. Allele-specific PCR assay to genotype SNP rs7903146 in TCF7L2 gene for rapid screening of diabetes susceptibility. Arq Bras Endocrinol Metabol. 2008;52(8):1362-6.

30. Standards of medical care in diabetes--2006. Diabetes Care. 2006. p. S4-42.

31. Walsh PS, Metzger DA, Higuchi R. Chelex 100 as a medium for simple extraction of DNA for PCR-based typing from forensic material. BioTechniques. 1991;10(4):506-13.

32. Humphries SE, Gable D, Cooper JA, Ireland H, Stephens JW, Hurel SJ, et al. Common variants in the TCF7L2 gene and predisposition to type 2 diabetes in UK European Whites, Indian Asians and Afro-Caribbean men and women. $\mathrm{J} \mathrm{Mol} \mathrm{Med} \mathrm{(Berl).}$ 2006;84(12):1005-14.

33. Shu L, Sauter NS, Schulthess FT, Matveyenko AV, Oberholzer J, Maedler K. Transcription factor 7-like 2 regulates beta-cell survival and function in human pancreatic islets. Diabetes. 2008;57(3):645-53.

34. Drucker DJ. The biology of incretin hormones. Cell Metab. 2006;3(3):153-65.

35. Shu L, Zien K, Gutjahr G, Oberholzer J, Pattou F, Kerr-Conte J, et al.TCF7L2 promotes beta cell regeneration in human and mouse pancreas. Diabetologia. 2012;55(12):3296-307. 